\title{
Book review: Pre-Clovis in the Americas: International Science Conference Proceedings
}

\author{
Jennifer Anderson \\ Sims and Associates, LLC. 201 South Lakeline Boulevard, Suite 402, Cedar Park, Texas 78613, U.S.A. \\ Email: jennifer@simsassociates.net
}

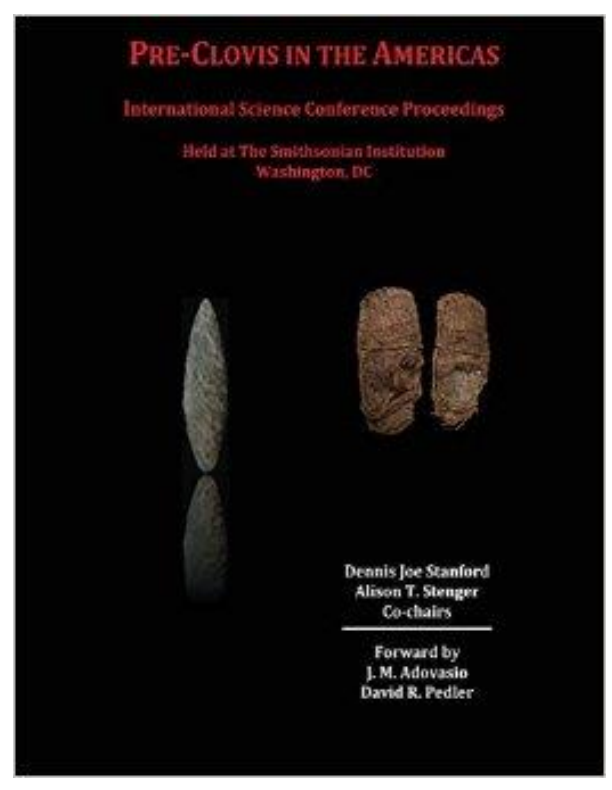

Pre-Clovis in the Americas: International Science Conference Proceedings

Co-Chaired by Dennis Joe Stanford and Alison T. Stenger

Smithsonian Institution, 2014, pp. 268. ISBN 978-1492747277

http://prehistoricterritory.org/pre-clovis-in-the-americas-international-science-conference-proceedings/

This volume is comprised of papers presented at the "Pre-Clovis in the Americas" conference, held in 2012 at the Smithsonian Institution in Washington, D.C. The conference was convened to discuss the current state of research concerning Pre-Clovis occupations in the Americas. The goals of the conference were twofold: to gain a better understanding of Pre-Clovis artifact assemblages and to identify possible patterning in those assemblages that could point to the origin or origins of Pre-Clovis. The eleven papers in this volume present data from numerous Pre-Clovis sites across North and South America and offer unique

Journal of Lithic Studies (2016) vol. 3, nr. 1, p. xx-xx

doi:10.2218/jls.v3i1.1453

Published by the School of History, Classics and Archaeology, University of Edinburgh ISSN: 2055-0472. URL: http://journals.ed.ac.uk/lithicstudies/

This work is licensed under a Creative Commons Attribution 2.5 UK: Scotland License. 
suggestions for identifying new sites and assemblages that predate Clovis occupations in the Americas.

The foreword by Adovasio and Pedler opens with a humorous, if slightly unsettling, rendition of Paul Martin's "les chasseurs" Clovis-first paradigm and its unprecedented fame among scholars. The authors caution that the notion of Pre-Clovis is not a singular, allencompassing replacement hypothesis for Clovis-first. The peopling process is too complex to be explained by a single hypothesis.

In the first paper, Stenger explains that Pre-Clovis archaeological assemblages often contain tools with stylistic or technological attributes that are not present in later assemblages. She raises the question of whether or not Pre-Clovis lithic technology could be a reliable proxy for determining founding population origins. Clark, Mitrovica and Alder then present a model for more accurately assessing LGM sea level changes that could have important implications for identifying a Siberian progenitor of Pre-Clovis. Their model found that the Bering Land Bridge was fully submerged by $11,000 \mathrm{BP}$, not 10,000 BP as previously thought.

The next several papers present information regarding Pre-Clovis assemblages in North America. Hemmings and Adovasio note that three lithic technologies that are known to have existed prior to Clovis in the eastern United States are also found in Florida: bipointed bifacial knives and points (of which Cinmar is a larger form), lozenge or triangular points that are similar to the Miller point, and Page-Ladson (or Delmarva) unfluted lanceolates. Wah, Lowery and Wagner then discuss a Pre-Clovis assemblage that was recovered from beneath a deeply buried paleosol capped by Miles Point Loess. Along the Delmarva Peninsula, the deposition of Miles Point Loess consistently coincides with the LGM. Next, Adovasio and Pedler present newly calibrated radiocarbon dates for Meadowcroft Rockshelter, Pennsylvania. There, the Pre-Clovis assemblage date range is 15,293-14,896 cal. BC $(1 \sigma)$. Johnson then discusses his model for finding new Cactus Hill-like sites. The Cactus Hill site is located within a sand dune; and, through a series of radiocarbon and OSL dates as well as cross-mending artifacts within Pre-Clovis and Clovis assemblages, it was determined that the stratigraphy was intact and none of the artifacts had been vertically translocated. Finally, Rice's paper on the Western Stemmed Point Tradition explores the possibility that this point tradition, associated with Bison antiquus in eastern Washington State and radiocarbon dated to $8700 \mathrm{RCYBP}$, may have greater time depth than previously thought. He points to the Channel Islands, where similar points were recovered and dated to 11,800-11,500 RCYBP, and to Mexico, where Angostura or Agate Basin-like points were identified in association with a mammoth.

In South America, Suarez found that the toolkits from three sites with securely dated PreFishtail components, Monte Verde II, Chile (14,600 cal. BP), Arroyo Seco 2, Argentina (14,667-13,359 cal. BP) and Piedra Museo, Patagonia, Argentina (15,000 cal. BP), predominately contained flake-based tools and unifacial tools with no apparent technological standardization. He notes that the widespread appearance of Fishtail points around 13,000 BP represents an abrupt shift in point technology. Gomes de Mello Araujo then discusses palaeoenvironment reconstruction in South America and the use of proxy indicators. $\mathrm{He}$ explains how pollen, speliothems and stable carbon isotopes each react differently to climatic fluctuations. He urges Paleoindian researchers to formulate geo-informed approaches when locating and interpreting new sites to explain the abrupt appearance of Clovis and Fishtail.

The final papers highlight data accumulation and interpretation biases that occur in PreClovis research. Adovasio points out that perishables generally form the bulk of material remains when they are recovered; yet, plant fibre technology receives very little consideration from North American archaeologists. Stenger discusses the preponderance of processing tools (e.g., crescents) versus projectile points that are recovered from submerged sites in Oregon. 
Were these tools part of terrestrial assemblages, later submerged due to rising sea levels, or did they have maritime uses?

The papers in this volume were contributed by many of the top archaeologists in the field. Though the nature of Pre-Clovis lithic technology is not well understood, the technological and typological details presented in this volume show a distinct pattern that is unlike Clovis or Fishtail. It remains to be seen if this unique technology can be used as a proxy for determining the origin or origins of Pre-Clovis. 